\title{
The Study of Site Selections of Green Open Space as a City Park in the Badung Regency
}

\author{
Putu Andre Wicaksana Putra ${ }^{1}$, Ngakan Putu Sueca ${ }^{2}$, Tri Anggraini Prajnawrdhi ${ }^{3}$
}

Program Study of Architecture, Faculty of Engineering, Udayana University

Faculty of Engineering, Udayana University

Denpasar, Bali

andreaverno64@gmail.com

Program Study of Architecture, Faculty of Engineering, Udayana University

Faculty of Engineering, Udayana University

Denpasar, Bali

Program Study of Architecture, Faculty of Engineering, Udayana University

Faculty of Engineering, Udayana University

Denpasar, Bali

\begin{abstract}
The density of a city affects the power to build an area. Regional development has a large impact on compaction and land cover on an area. This will certainly affect the reduced availability of open land, especially green open space (GOS) in an area. At the mandate of the government through Law No. 26 of 2007 concerning spatial planning it is required that within an area the availability of green open space be $30 \%$ of the total area. Badung Regency need for green space with a minimum area standard / capita of $0.3 \mathrm{~m} 2$ will obtain the area of green park needs of the City of $18,900 \mathrm{~m} 2$. The need for green space is then initiated by the Government of Badung Regency that the procurement will be followed by the provision of public space functions in the form of city parks. In the provision of green space in the form of city parks, a study of locations that will be used as city parks is needed. This location study begins by looking at locations that have potential by looking at accessibility, social, cultural, economic, and physical conditions as well as permits and regulations related to the land status. Therefore, it is deemed necessary to conduct a site study using the Analytical Hierarchy Process (AHP) method. That way it will be easier to conclude and determine the best location as a function of green open space as well as public open space in the form of city parks.
\end{abstract}

Keywords : Location, Green Open Space, City Park, Mangupura

\section{PREFACE}

The site availability along with Green Open Space functions (GOS) is a matter that is mentioned in the Law number 26, 2007, concerning spatial planning. It has been mentioned that in a region, the GS availability is $30 \%$ of the total area. This requirement has to be fulfilled with the established minimum number of GS.

City GOS is a critical component that affects human life quality, both ecologically or socio-psychologically. However, this day the proportion is gradually decreasing due to the high population density because of the high growth of the human population [1]. The increasing population is indirectly followed by increasing the demand for energy consumption and land to settle. This is not compensated by the land-use control to restrict human interventions against the urban natural environment [2].

Mangupura is the capital city of the Badung Regency. It functioned as the central government and economy and has caused regional development and society to grow significantly. The GOS requirements can function as a social activity medium, and as an aesthetic value point and a landmark, then the GOS is required in Mangupura.

The total Urban Area in Mangupura is 3.587 hectares. Following the Spatial Management Regulations number 26, 2007, explained that the GOS of Urban Area is 30\% from total urban area consisting of $20 \%$ Public GS and $10 \%$ Private GOS. Based on the calculation, the GOS area 
requirement is $30 \%$, then the Urban Area of Mangupura ideally requires 1076,1 hectares for GS allotments with the proportion: 717,4 Hectares for Public GOS and 358,7 Hectares for Private GOS.

To overcome that matter, the Badung Regency Government is exerting an effort to increase the GOS area. Badung Regency Government has the purpose of providing the GOS alongside with the recreation function in a city park form and later will be called Mangupura City Park. This city park targets to have functions such as ecology function support, socio-cultural, aesthetic, and social economy function. By that matter, it has to be conducted to study sites in order to find out the sites that match the purposes.

\section{Method OF Site SELECTION StUdy}

The method used to study and to determine the site of Mangupura City Park provision is the scoring method by the Analytical Hierarchy Process (AHP).

The main principle of the AHP method is to simplify the complex and unstructured problem into parts that can be arranged in a hierarchy. Each level of interest in every variable marked with numeric value is subjective concerning the critical meaning of the variable rather than other variables [3].

The AHP method is used to evaluate and select the best alternative based on certain criteria consideration that is used as a basis for assessments. In the trace of the mathematical equation and calculation process applied, the AHP process essentially forms the matrix that states relative interest value from an attribute towards another. In applying the AHP method, human perception is used as the main input to state the relation between attributes and the first step to resolve the problem.

In this research, the AHP method will be used to find the hierarchy from several complex variables in defining the site properness as the city park. Some aspects must be used as the priority criteria and supporting criteria summarized using the AHP method. The site will be determined by score potency weighting from one site to another from the hierarchy determination.

\section{GREEN OPEN SPACE (GOS)}

It is a category from which the whole open space consists of plants and vegetation (endemic, introduction) to support GOS benefits such as security, amenity, prosperity, and beauty. GOS can also be defined as follows [4].

Open space on its establishment has functions such as 1) To provide light and air circulation into the building especially on a tall building in the center of the town; 2) To bring the perspective impression and vista to urban scenes, mainly on the dense area in the center of the town; 3) To provide recreation area in specific activities form; 4) To protect the area ecology function; 5) To give "solid-void" in the city area; 6) As a reserved area for future application (development reserve area) [5].

From the statement above, it can be concluded that the GOS is one of the categories from open space that mainly focused on greening availability; plants, trees, shrubs, bushes, and many more. It is green, but it is how the space functions as well as space where the lights in and air turbulence are. Aesthetically, the GOS functions to form the perspective impression and vista on urban scenes, especially in the full building area.

\section{GOS ON ITS FunCTION AS A CITY PARK}

Public GOS is a GOS that is owned and managed by the local government (city/regency), and it is used for public concerns in general [6].

Started that a city park is an open space with social and aesthetic functions as a recreational activity medium, education, and other activity on the city level. A city park is intending to serve the citizens of city parts. This park serves with a minimum standard $0,3 \mathrm{~m} 2$ per citizen, with a minimum total park area $144.000 \mathrm{~m} 2$. This park can be in the form of a green field (GOS) with recreational and sports facilities, and a sports complex with $80 \%-90 \%$ of minimum GOS. All those facilities are open to the public. A city park can create a sense of place, to be a landmark, and as an assembly point for communities [7].

\section{Mangupura City Conditions}

TABLE I

THE NUMBERS OF THE TOTAL POPULATION IN BADUNG REGENCY IN 2014 -

\begin{tabular}{llllll}
\multicolumn{5}{c}{ Year } \\
\hline Village & $\mathbf{2 0 1 4}$ & $\mathbf{2 0 1 5}$ & $\mathbf{2 0 1 6}$ & $\mathbf{2 0 1 7}$ & $\mathbf{2 0 1 8}$ \\
Mengwi & 7.538 & 7.574 & 7580 & 7.599 & 7.689 \\
Gulingan & 7.699 & 7.696 & 7730 & 7.73 & 7.865 \\
Mengwitani & 6.861 & 6.802 & 6810 & 6.813 & 7.023 \\
Kekeran & 3.67 & 3.693 & 3690 & 3.698 & 3.847 \\
Kapal & 11.266 & 11.487 & 11900 & 11.502 & 11.95 \\
Abianbase & 5.787 & 5.846 & 5870 & 5.874 & 5.991 \\
Lukluk & 6.964 & 7.256 & 7140 & 7.148 & 7.353 \\
Sempidi & 5.487 & 5.5 & 5684 & 5.684 & 5.749 \\
Sading & 7.064 & 7.126 & 7250 & 7.262 & 7.511 \\
Total & $\mathbf{6 2 . 3 3 6}$ & $\mathbf{6 2 . 9 8 0}$ & $\mathbf{6 3 . 6 5 4}$ & $\mathbf{6 3 . 3 1 0}$ & $\mathbf{6 4 . 9 7 8}$
\end{tabular}

Source: Central Bureau of Statistics, Badung Regency in the year 2019

Based on the data from the Central Bureau of Statistics in 2019, the Urban Area land usage in Mangupura, 2018, consists of the usage of the existing built land of 1149,7 Hectares $(23,3 \%)$ and the unbuilt land is 2451 Hectares (76,7\%). The Urban Area population in Mangupura is 64.978 inhabitants, with a growth rate of $2,97 \%$ year counted from 2013. With total area 3587 Hectares, the density area of Urban Areas in Mangupura: 1881 inhabitants/Km2. 


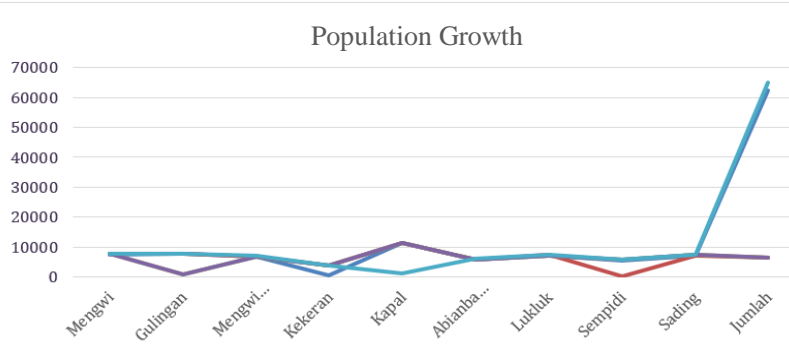

Fig. 1. Population Growth Rate in Mangupura City, Badung Regency Source: Data analysis results in a form of numbers from the Central Bureau of Statistics, Badung Regency, 2019

From the types of GOS in the Badung Regency according to Ministerial Regulations of Public Works Number 05/PRT/M/2008, the GOS area in Badung Regency is 7.626,76 Hectares. The most extensive GOS area is a city forest of 5.707,59 Hectares. The GOS area percentage of city forest towards the total GOS is $74,84 \%$, and the percentage towards the total area of the regency is $14,41 \%$. The GOS distribution in each sub-districts is very varied. As it viewed from the total area, the biggest sub-district until the smallest is Petang, South Kuta, Mengwi, Kuta, Abiansemal, and North Kuta with each total area around 5.414, 1.373, 353, 215, 118, dan 93 Hectares (see table 2). If it compares to the whole area of Badung Regency, the GOS scale in the Badung Regency is $19,26 \%$, or in other words, it has a total of 7.626,76 Hectares. The GOS distribution in Badung Regency is shown in the table below:

TABLE II

THE GOS DISTRIBUTION IN THE BADUNG REGENCY

\begin{tabular}{|c|c|c|c|c|c|c|c|c|c|c|}
\hline \multirow{3}{*}{ 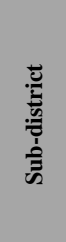 } & \multicolumn{9}{|c|}{ The GOS existing total area (Ha) } & \multirow[b]{3}{*}{ 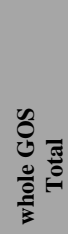 } \\
\hline & \multirow[b]{2}{*}{ 离 } & \multirow[b]{2}{*}{ 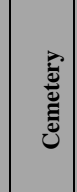 } & \multirow[b]{2}{*}{ İ } & \multicolumn{6}{|c|}{ Riparian area } & \\
\hline & & & & 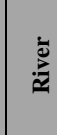 & $\begin{array}{l}\overrightarrow{\mathrm{g}} \\
\tilde{\tilde{g}} \\
\tilde{\delta}\end{array}$ & 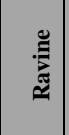 & 苛 & 5 & 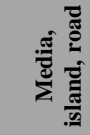 & \\
\hline 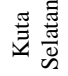 & $\begin{array}{l}421,5 \\
8\end{array}$ & 10,45 & $\begin{array}{l}151, \\
23\end{array}$ & $\begin{array}{l}143 \\
61\end{array}$ & $\begin{array}{l}165 \\
61\end{array}$ & $\begin{array}{l}458 \\
25\end{array}$ & - & 5,99 & 16,40 & $\begin{array}{l}1.37 \\
3,13\end{array}$ \\
\hline 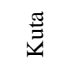 & 70,43 & 3,77 & $\begin{array}{l}30,8 \\
4\end{array}$ & $\begin{array}{l}20,3 \\
1\end{array}$ & $\begin{array}{l}75,1 \\
8\end{array}$ & - & 0,86 & 1,52 & 11,95 & $\begin{array}{l}214, \\
85\end{array}$ \\
\hline 蛋葋 & - & 1,82 & 3,06 & $\begin{array}{l}41,5 \\
5\end{array}$ & $\begin{array}{l}46,4 \\
2\end{array}$ & - & - & - & 0,57 & $\begin{array}{l}93,4 \\
3\end{array}$ \\
\hline 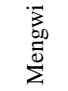 & - & 8,99 & 4,55 & $\begin{array}{l}241, \\
43\end{array}$ & $\begin{array}{l}37,5 \\
9\end{array}$ & - & - & 57,72 & 2,87 & $\begin{array}{l}353 \\
15\end{array}$ \\
\hline 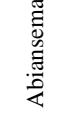 & 13,64 & 3,18 & 1,55 & $\begin{array}{l}148, \\
47\end{array}$ & - & - & - & 10,79 & - & $\begin{array}{l}117, \\
63\end{array}$ \\
\hline 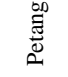 & $\begin{array}{l}5.201, \\
94\end{array}$ & 3,14 & 4,26 & $\begin{array}{l}190, \\
07\end{array}$ & - & $\begin{array}{l}12,2 \\
2\end{array}$ & - & 2,68 & 0,25 & $\begin{array}{l}5.41 \\
4,57\end{array}$ \\
\hline 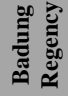 & $\begin{array}{l}\mathbf{5 . 7 0 7 ,} \\
\mathbf{5 9}\end{array}$ & 31,35 & $\begin{array}{l}195 \\
50\end{array}$ & $\begin{array}{l}785 \\
44\end{array}$ & $\begin{array}{l}324, \\
81\end{array}$ & \begin{tabular}{|l|}
470 \\
47
\end{tabular} & 0,86 & 78,70 & 32,04 & $\begin{array}{l}7.62 \\
6,76\end{array}$ \\
\hline
\end{tabular}

Source: The Open Space Planning Study and The Open Space Non-Green in Badung Regency.

\section{AREA REQUIREMENTS}

For the GOS area requirement in the form of a city park in the Mangupura Urban Area, according to the Ministerial Regulation of Public Works concerning the guidelines of GOS supply and utilization in the Urban Area, then the GOS requirement of a city park is as follow:

TABLE III

THE GOS REQUIREMENTS

\begin{tabular}{|c|c|c|c|c|}
\hline $\begin{array}{l}\text { Environment } \\
\text { Unit }\end{array}$ & $\begin{array}{l}\text { GOS } \\
\text { Type }\end{array}$ & $\begin{array}{l}\text { Minimal } \\
\text { Area/Unit } \\
(\mathrm{m} 2)\end{array}$ & $\begin{array}{l}\text { Minimal } \\
\text { Area/ } \\
\text { Capita } \\
\text { (m2) }\end{array}$ & $\begin{array}{l}\text { Site } \\
\text { Requirement }\end{array}$ \\
\hline \multirow{3}{*}{$\begin{array}{c}480.000 \\
\text { inhabitants }\end{array}$} & $\begin{array}{l}\text { City } \\
\text { Park }\end{array}$ & 144.000 & 0,3 & $\begin{array}{l}\text { in the center } \\
\text { area/town }\end{array}$ \\
\hline & $\begin{array}{l}\text { Clty } \\
\text { Forest }\end{array}$ & adjusted & 4,0 & inside/suburban \\
\hline & $\begin{array}{l}\text { Specific } \\
\text { Function }\end{array}$ & adjusted & 12,5 & $\begin{array}{l}\text { adjusted to } \\
\text { requirement }\end{array}$ \\
\hline
\end{tabular}

Source: Ministerial of Public Works regulation 05/PRT/M/2008 concerning the supply and utilization in the Urban Area

Based on the total number of population in 2018 (63.316 inhabitants) then it requires a city park as wide as 18.900 $\mathrm{m} 2$ (minimum standard area/capita $0,3 \mathrm{~m} 2$ ) while the requirement based on the projection of population in 2030 (323.334 inhabitants), it means that the GOS area requirement is $97.000 \mathrm{~m} 2$. Then, the target area $30 \%$ of the total city area can be reached in stages by the urban area allocation strategy typically. The GOS providing strategy in an urban city space can be started from the unbuilt spaces as infrastructure such as roads, parks, and many more. For the private GOS provisions as a supporting percentage, the GOS availability in Mangupura can be started using the unbuilt area in every private residential land. The garden and the house yard that is available because of KDB is a potency that can be utilized. Those strategies can be shown in the following picture. 


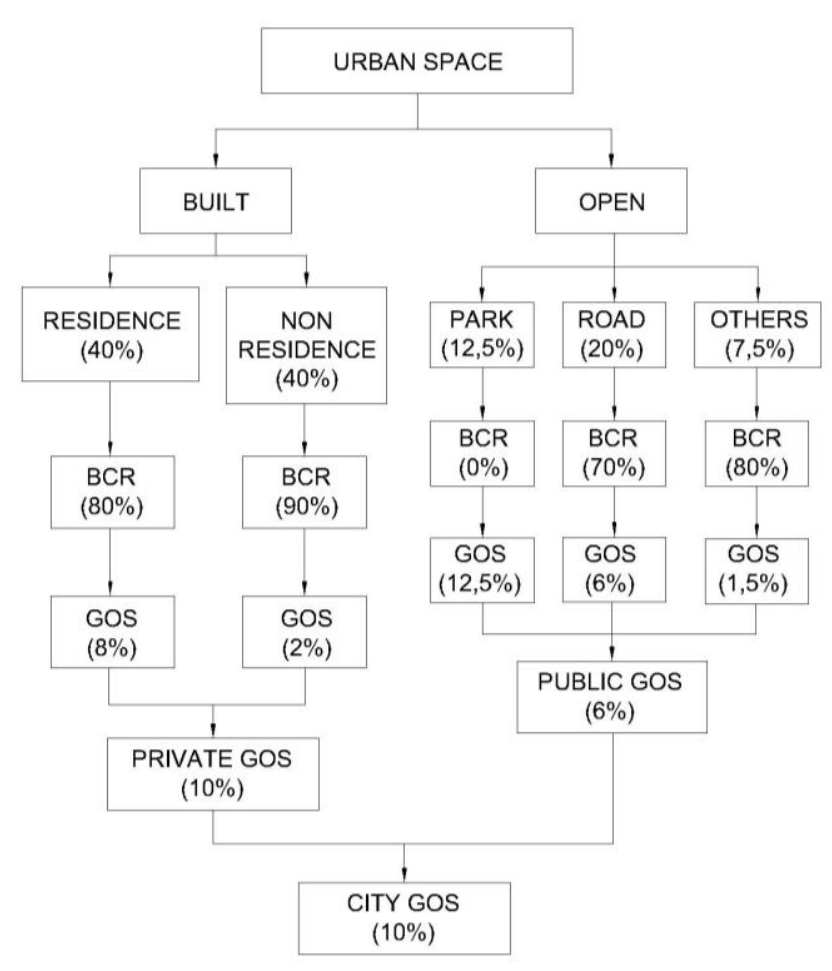

Fig. 2. The GOS providing strategy structure in the urban space

VII. Site PotenCy IDENTIFICATION

Based on the land composition data, an urban area in Mangupura consists of $31,93 \%$ of built land, and $68,07 \%$ of unbuilt land. After the area is measured, then the filtering is conducted on the unbuilt land by following the Regulations Number 41, 2009, concerning the protection of sustainable agricultural land (PSAL) and Local Regulations of Badung Regency number 26, 2013, concerning the spatial planning management in the Badung Regency 2013-2033. The filtering was conducted to find out the alternative sites in order to correspond with the instruction of protection of sustainable agricultural land and with the local regulation about the RTRW in the Badung Regency. The unbuilt land category that is not proper for the filtered city park development site is the sustainable agricultural land, and also the land that is not according to the local regulations number 26, 2013, concerning the spatial planning management in the Badung Regency area 2013-2033.

Based on the data processing result by satellite imagery, geospatial information data, and field survey, the site alternative of Mangupura Urban Area City Park will be divided based on the existing conditions and the space pattern planning structure with the total 17 sites. All numbers and GOS distribution can be seen in the map below:

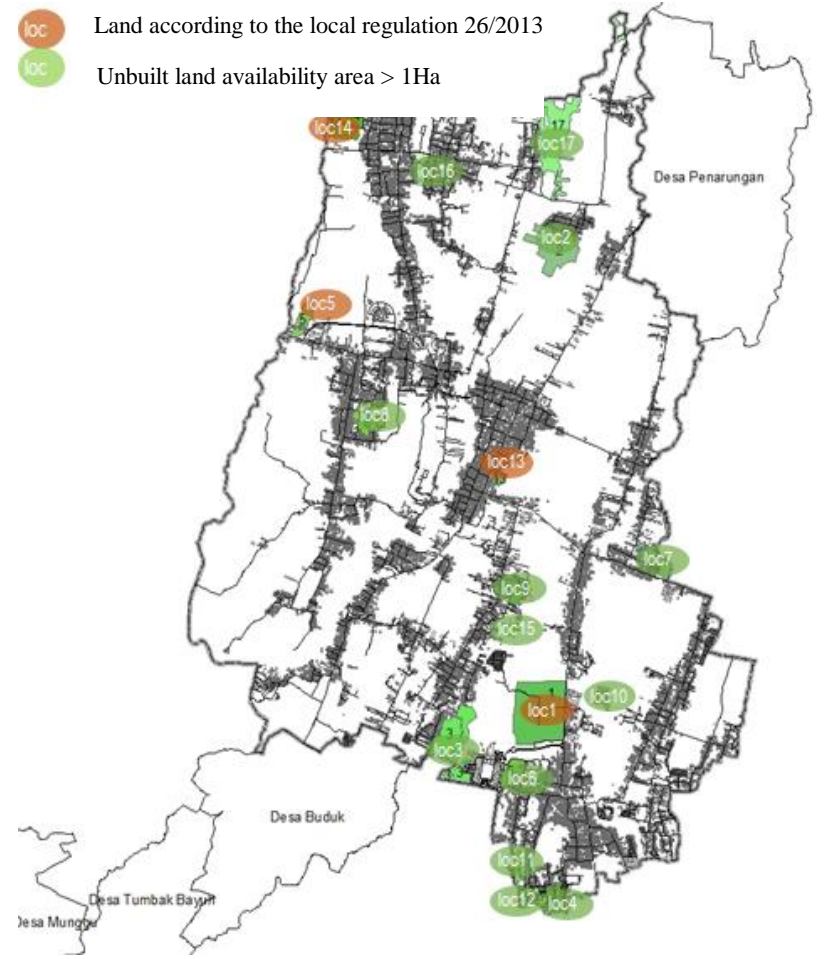

Fig. 3. Potential distribution of the location of Mangupura City Park

VIII. Site Analysis Based on the ACCeSSIBILITy (CENTRALIty INDEX)

Based on the Ministerial Regulation of Public Works 05/PRT/M/2008 concerning the GOS supply and utilization in the Urban Area. The GOS City Park type requires the location requirement. The GOS city park type requirement has to be near the center of the city. The center activity in the urban area can be seen by the facility's location in cityscale service.

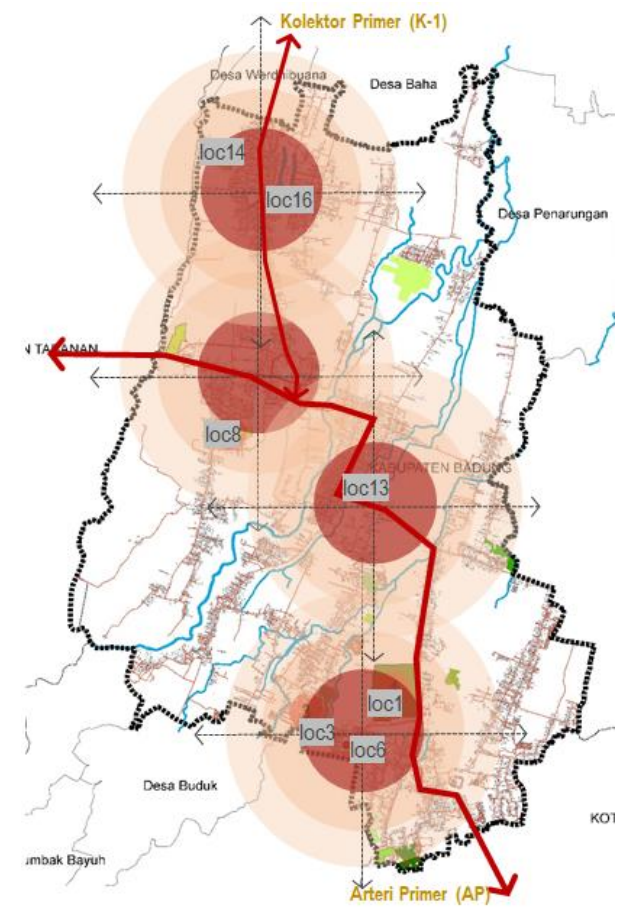

Fig. 3. Analisis indeks sentralitas alternatif lokasi Taman Kota Mangupura TABLE IV 
THE ANALYSIS OF ALTERNATIVE CENTRALITY INDEX OF MANGUPURA CITY PARK SITES

\begin{tabular}{lllll}
\hline $\begin{array}{l}\text { Environment } \\
\text { Unit }\end{array}$ & GOS type & $\begin{array}{l}\text { Minimum } \\
\text { area/unit } \\
\text { (M2) }\end{array}$ & $\begin{array}{l}\text { Minimum } \\
\text { area/capita } \\
(\mathrm{m} 2)\end{array}$ & $\begin{array}{l}\text { Site } \\
\text { requirement }\end{array}$ \\
\hline & city park & 144.000 & 0.3 & $\begin{array}{l}\text { Center of } \\
\text { the city }\end{array}$ \\
\hline
\end{tabular}

Based on the analysis result, sites 1 allotment according to the RTRW guideline of Badung regency is for the GOS allotment area, and according to the RDTR guideline of Mengwi sub-district is GOS-1 zone. Site 3 allotments according to the RTRW guideline of Badung regency is for Food Crop Agriculture (FCA), residential, and GOS, and according to the RDTR of Mengwi sub-district is for food crop agriculture zone. Site 6 allotments according to the RTRW guideline of Badung regency is for residential area and office area, and according to the RDTR Mengwi subdistrict is for regency level office area and housing zone. Site 8 according to the RTRW Badung regency is for GOS allotment and residential, and according to the RDTR Mengwi sub-district is for housing zone and cemetery Site 13 and 14 according to the RTRW Badung regency is for GOS allotment, and according to the RDTR Mengwi subdistrict is for GOS-1 zone and public service facilities (PSF). Site 16, according to the RTRW Badung regency, is for residential area and, according to the RDTR Mengwi sub-district, is for public service facilities.

TABLE IV

LOCATION ANALYSIS BASED ON THE SUITABILITY OF THE DESIGNATION WITH THE SPATIAL LAYOUT

\begin{tabular}{|c|c|c|c|c|c|c|}
\hline No & Site/Location & Village/Ward & $\begin{array}{l}\text { Existing } \\
\text { Land } \\
\text { Usage }\end{array}$ & $\begin{array}{l}\text { Total } \\
\text { area } \\
(\mathrm{Ha})\end{array}$ & $\begin{array}{c}\text { Space } \\
\text { Pattern } \\
\text { Plan } \\
\text { (Local } \\
\text { regulation } \\
\text { 23/2013) }\end{array}$ & $\begin{array}{l}\text { Space } \\
\text { pattern } \\
\text { plan }\end{array}$ \\
\hline 1 & $\begin{array}{l}\text { Jl. Raya } \\
\text { Denpasar } \\
\text { Gilimanuk }\end{array}$ & $\begin{array}{l}\text { Sempidi } \\
\text { ward and } \\
\text { Lukluk ward }\end{array}$ & rice fields & 34.78 & GOS & GOS-1 \\
\hline 3 & $\begin{array}{l}\text { Jl. Raya } \\
\text { Abianbase }\end{array}$ & $\begin{array}{l}\text { Abianbase } \\
\text { ward }\end{array}$ & $\begin{array}{l}\text { plantations } \\
\text { (and } \\
\text { shrubs) }\end{array}$ & 14.98 & $\begin{array}{l}\text { FCA, } \\
\text { residential, } \\
\text { and GOS }\end{array}$ & $\begin{array}{l}\text { FCA } \\
\text { zone }\end{array}$ \\
\hline 6 & $\begin{array}{l}\text { Jl. Dalung } \\
\text { Sading }\end{array}$ & $\begin{array}{l}\text { Sempidi } \\
\text { ward }\end{array}$ & plantation & 4.79 & $\begin{array}{l}\text { residential } \\
\text { and office } \\
\text { area }\end{array}$ & $\begin{array}{l}\text { regency } \\
\text { office } \\
\text { and } \\
\text { housing } \\
\text { zone }\end{array}$ \\
\hline 8 & Jl. Gandamayu & $\begin{array}{l}\text { Mengwitani } \\
\text { village }\end{array}$ & plantation & 3.77 & $\begin{array}{l}\text { GOS and } \\
\text { residential }\end{array}$ & $\begin{array}{l}\text { housing } \\
\text { zone and } \\
\text { cemetery }\end{array}$ \\
\hline 13 & $\begin{array}{l}\text { Jl. Raya } \\
\text { Denpasar } \\
\text { Gilimanuk }\end{array}$ & Kapal ward & sport field & 1.43 & GOS & $\begin{array}{l}\text { GOS-1 } \\
\text { (PSF) }\end{array}$ \\
\hline 14 & Jl. Danau Toba & $\begin{array}{l}\text { Mengwi } \\
\text { ward }\end{array}$ & $\begin{array}{l}\text { sport } \\
\text { facilities }\end{array}$ & 1.43 & GOS & $\begin{array}{l}\text { GOS-1 } \\
\text { (PSF) }\end{array}$ \\
\hline 16 & Jl. Ayodya & $\begin{array}{l}\text { Mengwi } \\
\text { ward }\end{array}$ & shrubs & 3.0 & residential & $\begin{array}{l}\text { public } \\
\text { service }\end{array}$ \\
\hline
\end{tabular}

facilities

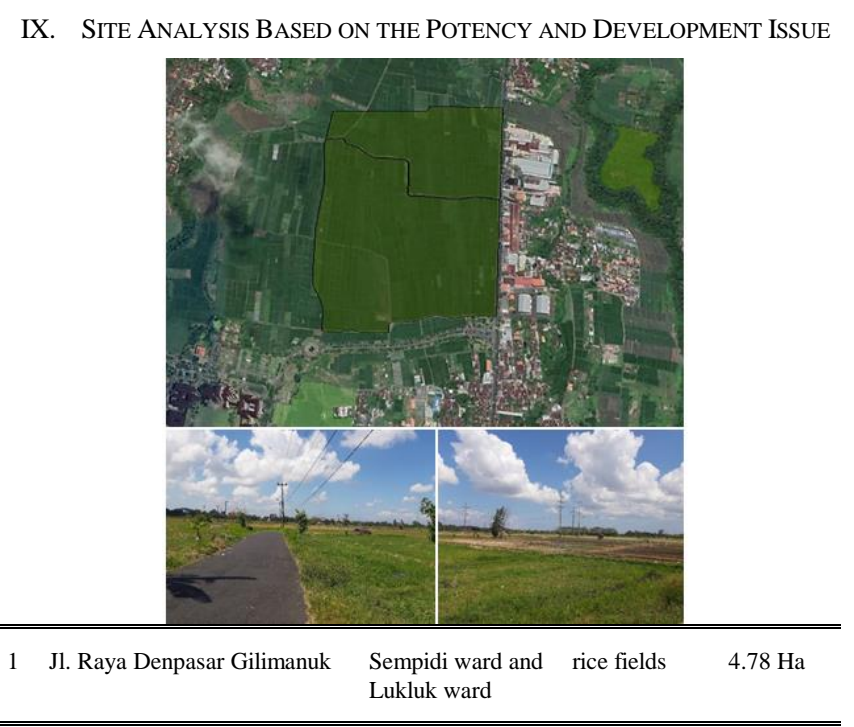

Fig. 4. Analysis result on site 1

\section{Development Potency:}

1) Enormous potency with a total area 34,78 Ha that is quite enough to develop a city park; 2) Flat topography site condition $(0,5 \%)$, no cut, and fill needed. The land is ready to develop; it only needs to form the soil surface; 3 ) High accessibility, located on the main road (primary lane). Very high public engagement; 4) It is not in the disaster-prone areas (flood and landslide); 5) Near the area service center (Badung Central Government Office); 6) Local regulation 26/2013 as a Green Open Space (GOS) allotment, and it supported by matek RDTR as GOS-1 (GOS park).

\section{Development Issue:}

1) The existence of productive agricultural land (PSAL scale rekom3); 2) High-cost land acquisition, Sales Value of Taxable Object Rp. 5.625.000/m2 (land acquisition estimation is 500 billion).

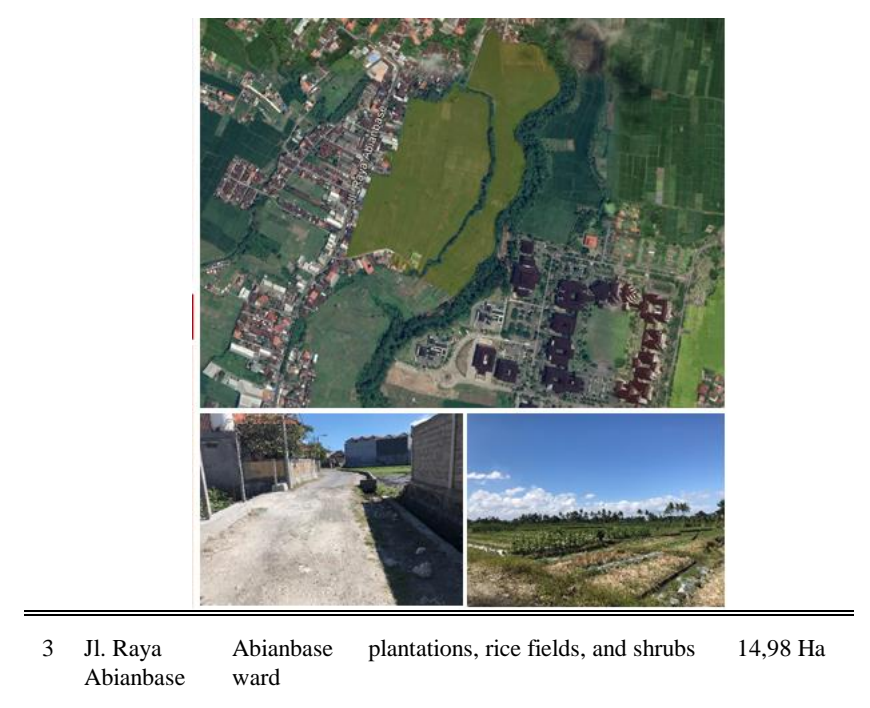

Fig. 5. Analysis result on site 3

Development potency: 
1) It has sufficient land area to develop the city park $(14,98$ $\mathrm{Ha})$; 2) Quite flat topography site condition (2,5\%). It requires a small cut and fill. The land is ready to develop; it only needs to form the soil surface; 3 ) It is not in the disaster-prone areas (flood and landslide); 4) Near to the residential center and activity center; 5) Near the area service center (Badung Central Government Office); 6) Sales Value of Taxable Object Rp. 1.573.000/m2 (land acquisition estimation is 30 billion).

\section{Development issue:}

1) Site accessibility is an environmental road class. It has limited access ( 4 and 2 wheeled vehicles), and it is not public accessibility; 2) The site form is not quite in flat condition, and it requires site improvement on the soil surface for a city park; 3) Mixed productive lands (rice field and plantation).

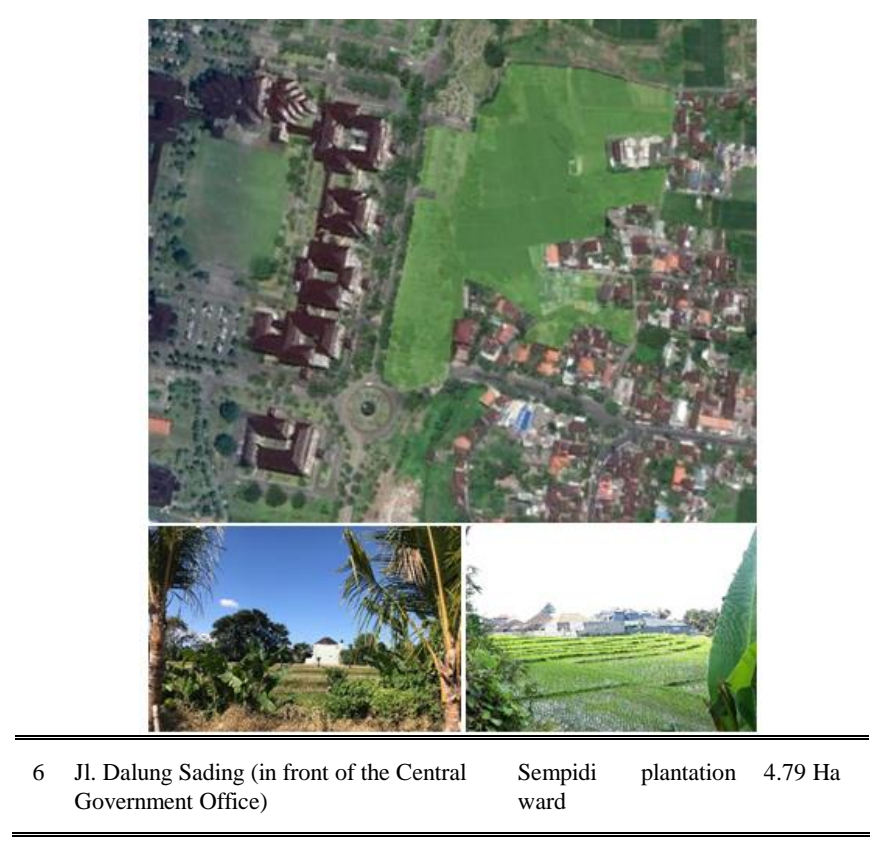

Fig. 6. Analysis result on site 6

\section{Development potency:}

1) Quite a strategic land site, located in front of taman jepun Badung Central Government Office, so if it takes further development, it can be integrated with the taman jepun; 2) Collector class road accessibility. It has one road with the entrance of the Badung Central Government Office; 3) Flat topography site condition (0-5\%). It requires no cut and fill. The land is ready to develop; it only needs to form the soil surface; 4) It is not in the disaster-prone areas (flood, earthquake, and landslide); 5) Near to the residential center and activity center; 6) Near to the residence area and public service center area; 7)Sales Value of Taxable Object Rp. $3.100 .000 / \mathrm{m} 2$ (land acquisition estimation is 60 billion).

\section{Development issue:}

1) Some parts are still in productive land (rice fields) and some are residential; 2) Office and residential allotments (local regulation 26/2013); 3) It has irregular form sites and it requires symmetrical site improvement for city parks.

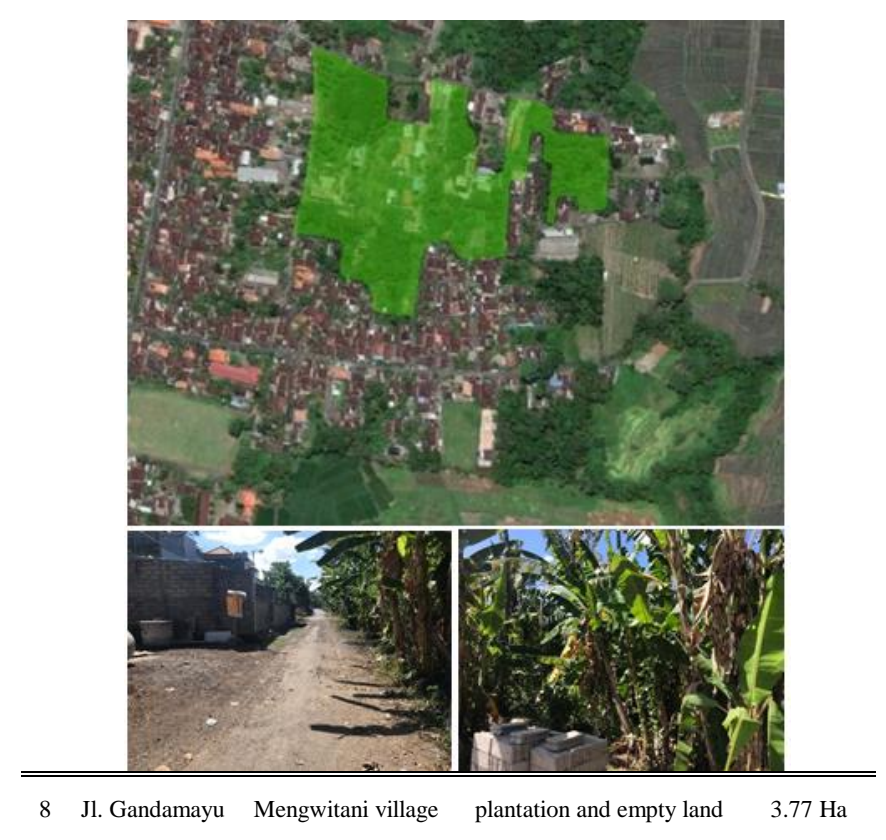

Fig. 7. Analysis result on site 8

\section{Development potency:}

1) Flat topography site condition (0-5\%). It requires no cut and fill. The land is ready to develop; it only needs to form the soil surface; 2) It is not productive land (rice field and productive plantation); 3) It is not in the disaster-prone areas (flood, earthquake, and landslide); 4) Near to the residential center and activity center; 5) Sales Value of Taxable Object Rp. 1.722.000/m2 (land acquisition estimation is 33 billion).

Development issue:

1) The total area is sufficient (3,77 Ha); however, there is plenty of development around it; 2) Environmental road class. Limited access for 2-4 wheeled vehicles, and it is not public accessibility; 3) There are no public/city services within a 500m radius; 4) The total number of population that can be served <15.000 inhabitants; 5) It has irregular form sites, and it requires symmetrical site improvement for city parks. Located in the middle of the residences. 


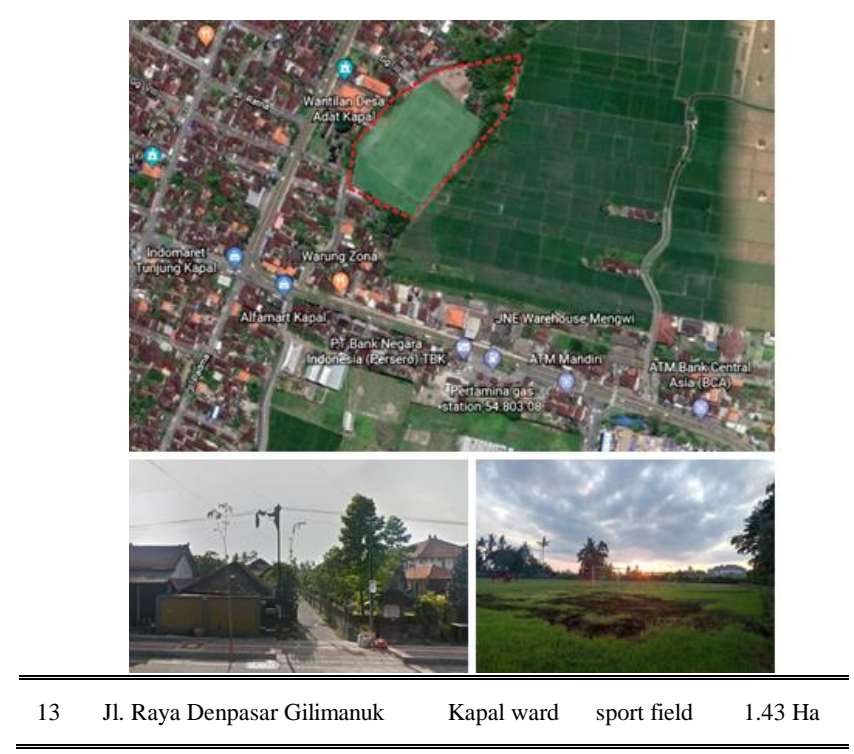

Fig. 8. Analysis result on site 13

\section{Development potency:}

1) Flat topography site condition $(0-5 \%)$. It requires no cut and fill. The land is ready to develop; it only needs to form the soil surface; 2) It is not productive land (rice field and productive plantation); 3) It is not in the disaster-prone areas (flood, earthquake, and landslide); 4) Near to the residential center and activity center; 5) Sales Value of Taxable Object Rp. 537.000/m2 (land acquisition estimation is 7,6 billion).

\section{Development issue:}

1) The total area is sufficient $(1,43 \mathrm{Ha})$; however, there is plenty of development around the site; 2) Located behind the Kapal Hall. Environmental road class. Limited access for 2-4 wheeled vehicles, and it is not public accessibility; 3) The existing site is a sports field, and it is located in the middle of residences; 4) Substantially, it will add a new GOS for KP Mangupura. It is a PSF allotment for sports facilities.

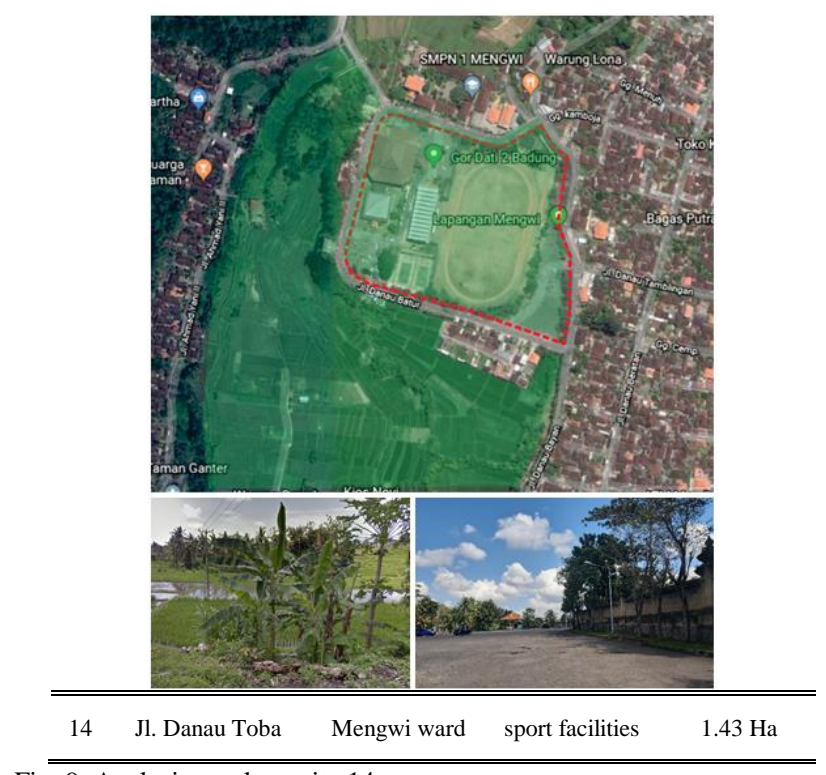

Fig. 9. Analysis result on site 14

\section{Development potency:}

1) Flat topography site condition (0-5\%). It requires no cut and fill. The land is ready to develop. It only needs to form the soil surface; 2) It is not productive land (rice field and productive plantation); 3) Space allotment according to RTRW (GOS-1; 4) It is not in the disaster-prone areas (flood, earthquake, and landslide); 5) Near to the residential center and activity center; 6) Sales Value of Taxable Object Rp.6.805.000/m2 (land acquisition estimation is 20 billion).

Development issue:

1) The total area is sufficient $(1,43 \mathrm{Ha})$. The existing land is PSF (sport building), and it requires a GOS extension.; 2) Collector road accessibility, it can be passed by $2 / 4$ wheeled vehicles; 3) For land extension is still having an issue of status confirmation as a sustainability agricultural land.

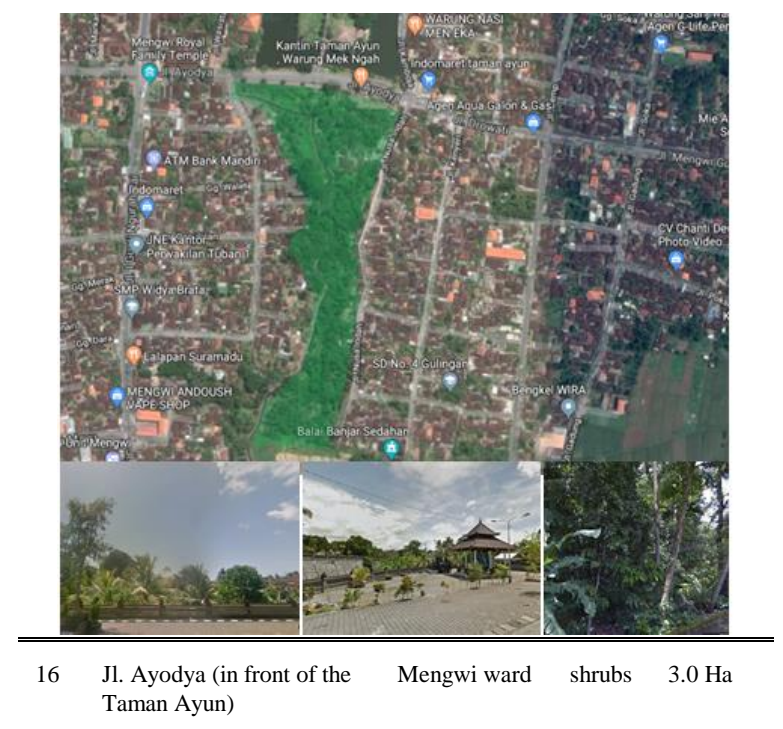

Fig. 10. Analysis result on site 16

\section{Development potency:}

1) Flat topography site condition $(0-5 \%)$. It requires no cut and fill. The land is ready to develop. It only needs to form the soil surface; 2) It is not productive land (rice field and productive plantation); 3) It is not in the disaster-prone areas (flood, earthquake, and landslide); 4) Near the residential center and activity center (Taman Ayun).

\section{Development issue:}

1) The total area is sufficient (3,00 Ha); however, there is plenty of development around the site; 2) Collector road accessibility, it can be limited to $2 / 4$ wheeled vehicles; 3 ) The total number of population that can be served $<15.000$ inhabitants; 4) It has irregular form sites, and it requires symmetrical site improvement for city parks. Located in the middle of the residences.

\section{Analytical Hierarchy Process (AHP)}

The AHP method used to gain the sequence from several alternative compatibilities to GOS site criteria as a city park. The sites alternative by AHP scoring has been 
complete by 9 (nine) criteria such as total area, a land that is already developed; it is non-productive land, it is not in the disaster-prone area, near to the residential center or activity center, ease of accessibility, sites requirement based on the total population, city service, and land prices. The information on the criteria is shown in the table below:

TABLE V

GOS PROVIDING CRITERIAS AS A CITY PARK IN BADUNG REGENCY.

\begin{tabular}{lll}
\hline No & Criteria & \multicolumn{1}{c}{ Information } \\
\hline 1 & Total area & $\begin{array}{l}\text { The Green City Development Program } \\
\text { (GCDP) guideline from Ministry of Public } \\
\end{array}$ \\
& $\begin{array}{l}\text { Works and Public Housing stated that the } \\
\text { GOS providing with 1 Ha minimum and }>1 \\
\text { for the better. }\end{array}$
\end{tabular}

2 Developed land No land dredging necessary or sandfill except for soil surface forming (clean and clear).

3 Non-productive It is non-productive land such as rice fields, land plantation, etc. The higher the productivity it means the worse it can be and vice versa.

4 Not in the the higher the number of the disaster disaster-prone occurred it means the lower the price of the area land.

5 Near the within $500 \mathrm{~m}$ radius. residential ot activity center

6 Ease of accessibility

Public transportation and 2/4 wheeled vehicles are easily passed..

7 Site requirement The higher the number of the population the based on the better.

total population

TABLE VI

CRITERIA ACCORDING TO THE OPINION OF THE EXPERTS..

\begin{tabular}{|c|c|c|}
\hline & Priority criteria & Supporting criteria \\
\hline $\begin{array}{l}\text { Expert } 1 \\
\text { (IAP) }\end{array}$ & $\begin{array}{l}\text { - located not in the disaster-prone } \\
\text { area } \\
\text { - non-productive area } \\
\text { - ease of accessibility } \\
\text { - near to the residential or activity } \\
\text { center } \\
\text { - City services }\end{array}$ & $\begin{array}{l}\text { - total area } \\
\text { - developed land } \\
\text { - site requirements } \\
\quad \text { based on the } \\
\text { total population } \\
\text { - land prices }\end{array}$ \\
\hline $\begin{array}{l}\text { Expert } 2 \\
\text { (IAI) }\end{array}$ & $\begin{array}{l}\text { - located not in the disaster-prone } \\
\quad \text { area } \\
\text { - non-productive area } \\
\text { - developed land } \\
\text { - ease of accessibility } \\
\text { - near to the residential or activity } \\
\quad \text { center and city services }\end{array}$ & $\begin{array}{l}\text { - site requirements } \\
\text { based on the } \\
\text { total population } \\
\text { - total area and } \\
\text { land prices }\end{array}$ \\
\hline $\begin{array}{l}\text { Expert } 3 \\
\text { (PWK } \\
\text { UNHI) }\end{array}$ & $\begin{array}{l}\text { - located not in the disaster-prone } \\
\text { area } \\
\text { - non-productive area } \\
\text { - ease of accessibility } \\
\text { - developed land } \\
\text { - near to the residential or activity }\end{array}$ & $\begin{array}{l}\text { - total area } \\
\text { - site requirements } \\
\text { based on the } \\
\text { total population } \\
\text { - city services }\end{array}$ \\
\hline
\end{tabular}

center and city services

\begin{tabular}{|c|c|c|}
\hline $\begin{array}{l}\text { Expert } 4 \\
\text { (ARSITE } \\
\text { KTUR } \\
\text { UNUD) }\end{array}$ & $\begin{array}{l}\text { - located not in the disaster-prone } \\
\text { area } \\
\text { - non-productive area } \\
\text { - developed land } \\
\text { - ease of accessibility } \\
\text { - near to the residential or activity } \\
\text { center and city services }\end{array}$ & $\begin{array}{l}\text { - total area, site } \\
\text { requirements } \\
\text { based on the } \\
\text { total } \\
\text { population, and } \\
\text { city services } \\
\text { - city prices }\end{array}$ \\
\hline $\begin{array}{l}\text { Expert } 5 \\
\text { (PUPR) }\end{array}$ & $\begin{array}{l}\text { - developed land } \\
\text { - ease of accessibility } \\
\text { - near to the residential or activity } \\
\text { center } \\
\text { - city services } \\
\text { - site requirements based on the } \\
\quad \text { total population }\end{array}$ & $\begin{array}{l}\text { - land prices } \\
\text { - non-productive } \\
\text { area }\end{array}$ \\
\hline $\begin{array}{l}\text { Expert } 6 \\
\text { (DLHK) }\end{array}$ & $\begin{array}{l}\text { - located not in the disaster-prone } \\
\text { area } \\
\text { - total area and site requirements } \\
\text { based on the total population } \\
\text { - ease of accessibility and city } \\
\text { services }\end{array}$ & $\begin{array}{l}\text { - near to the } \\
\text { residential or } \\
\text { activity center } \\
\text { and city } \\
\text { services } \\
\text { - non-productive } \\
\text { area and } \\
\text { developed land } \\
\text { - land prices }\end{array}$ \\
\hline
\end{tabular}

TABLE VII

TABULATION RESULT OF THE EXPERTS TO THE ALTERNATIVE SITES

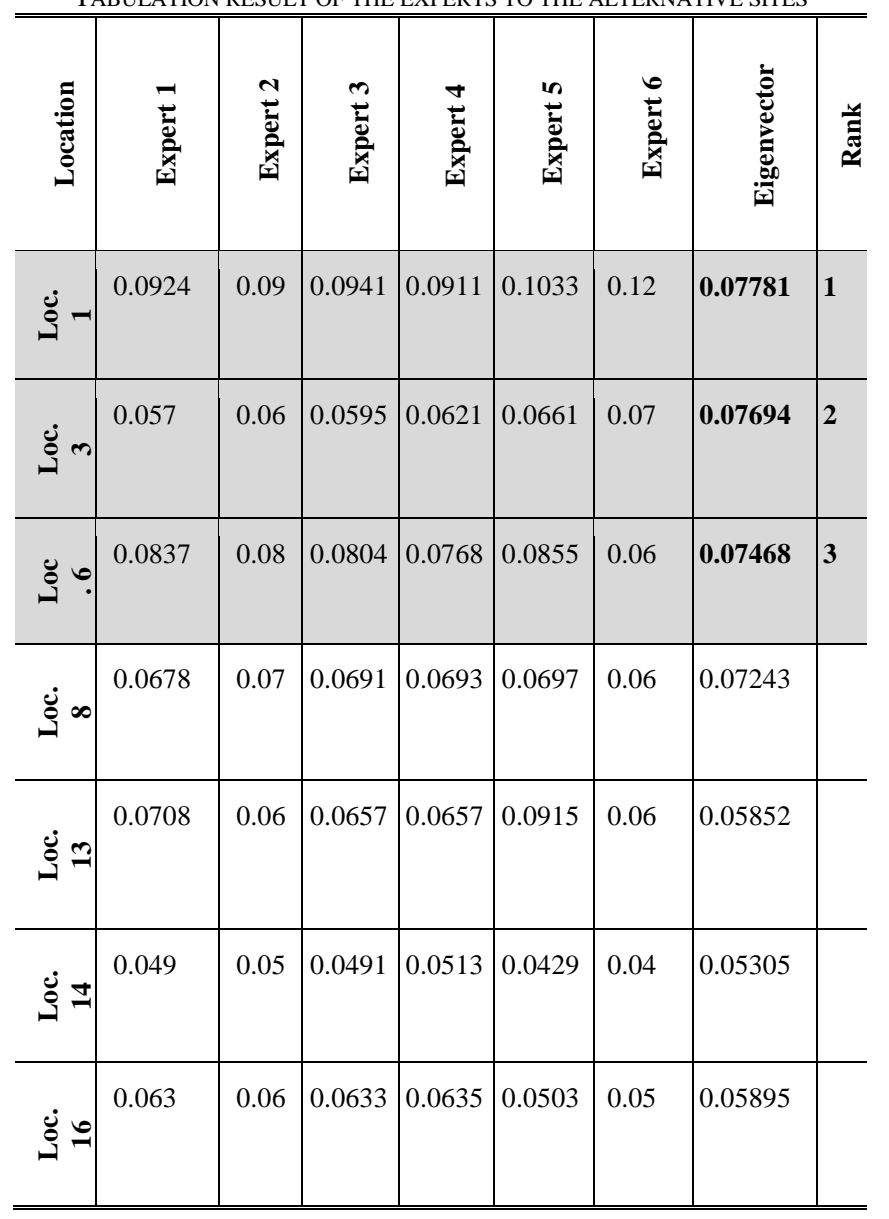

According to the arranged criteria above, the questionnaire is distributed to six experts to define the priority criteria and supporting criteria in defining the 
alternative sites of Mangupura city park. The experts are consist of 2 practitioner experts (the Association of Certified Planners), two experts from academics (Urban and Regional Planners, Hindu University of Indonesia, and Architecture of Udayana University), and two experts from (Service Office of Environment and Forestry and Service Office of Public Works and Spatial Planning).

Based on those criteria, next, the alternative site condition is identified according to them. The identification will be helped by the primary data of field existing conditions and secondary data. The result is shown in this table below.

The practitioner experts are evenly stated in the priority criteria such as; Not in the disaster-prone area, nonproductive area, ease of accessibility, near the residential or activity center, and city services. The supporting criteria, such as site requirements based on the total population and total land area and also land prices.

The academic experts are evenly stated in the priority criteria such as; Not in the disaster-prone area, nonproductive area, ease of accessibility, near the residential or activity center, and developed land. The supporting criteria include total land area \& site requirement based on the total population \& city services; and land price criteria.

The government service experts stated the different priority criteria from the practitioners and the academics, such as ease of accessibility, city services, proximity to the residential or activity center, site requirement based on the total population, and developed land. The supporting criteria such as near to the residential or activity center; developed land \& non-productive land and land prices.

The characteristics of alternative sites, the weighting is conducted to the experts with the value interval 1,3,5,7,9. The result is arranged as follows.

TABLE VIII THE SITE WEIGHTING CALCULATION BY AHP APPROACH

\begin{tabular}{|c|c|c|c|c|c|c|c|c|c|}
\hline \multirow[b]{2}{*}{ 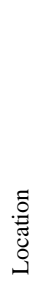 } & \multicolumn{9}{|c|}{ The site weighting calculation by AHP approach } \\
\hline & 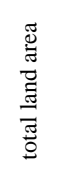 & 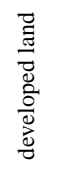 & 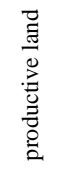 & 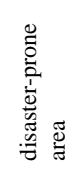 & 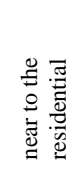 & 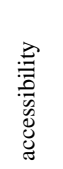 & 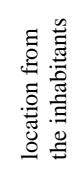 & 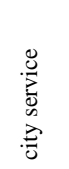 & 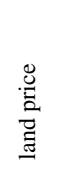 \\
\hline $\overrightarrow{0}$ & 0.29 & 0.07 & 0.09 & 0.07 & 0.07 & 0.12 & 0.10 & 0.09 & 0.29 \\
\hline 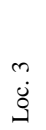 & 0.15 & 0.07 & 0.03 & 0.07 & 0.07 & 0.04 & 0.04 & 0.09 & 0.15 \\
\hline
\end{tabular}

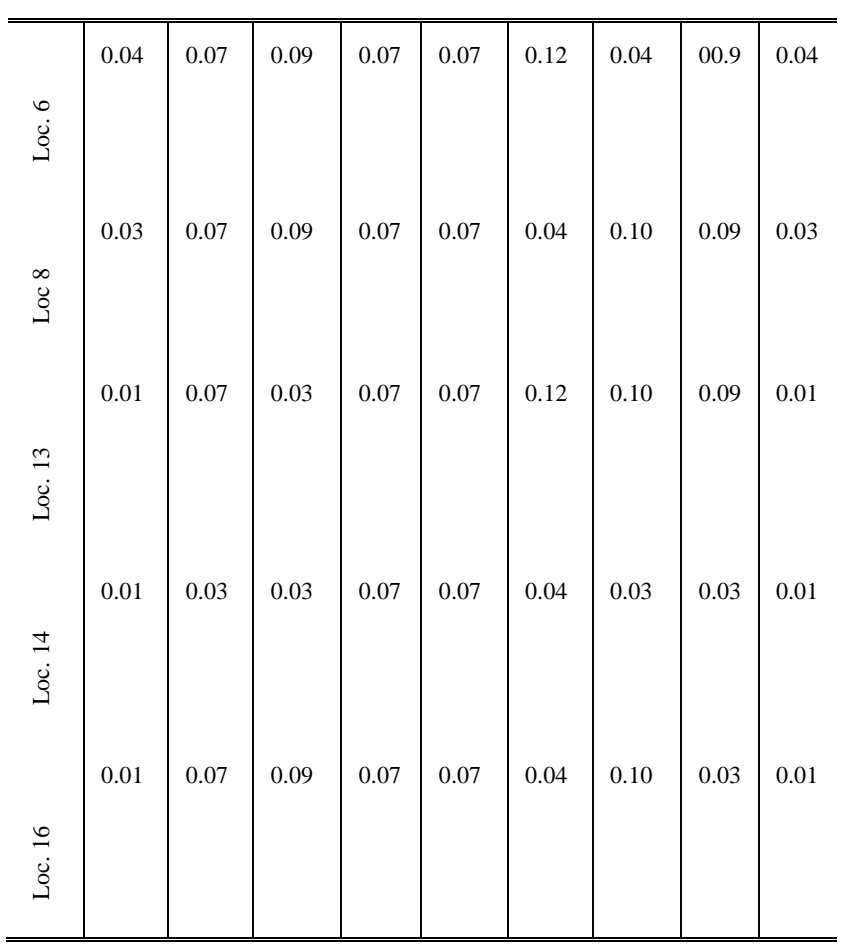

The site weight calculation recalculated to find the eigenvector, and it ranked according to the experts to find the most suitable alternative site. The result of the calculation is shown in the table below.

The previous location is analyzed by the AHP method and then re-tabulated using the same criteria using the SPSS application. Those criteria weighted with the intervals 0,1 , and 2. Next, the tabulation result is analyzed using the descriptive statistics analysis method. The result is shown in table VIII.

The descriptive statistics analysis is sequenced its rank by considering the average value from weighting tabulation. The result of the sequences resulted in the ranks in table IX.

TABLE IX

SITE WEIGHTING ACCORDING TO THE CRITERIA PARAMETER WITH SPSS

\begin{tabular}{|c|c|c|c|c|c|c|c|c|}
\hline Parameter & Criteria & 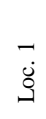 & 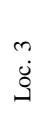 & $\begin{array}{l}0 \\
\dot{0} \\
\dot{J}\end{array}$ & $\begin{array}{l}\infty \\
\dot{g} \\
\dot{J}\end{array}$ & $\begin{array}{l}\stackrel{9}{\dot{0}} \\
\stackrel{0}{9}\end{array}$ & $\begin{array}{l} \pm \\
\dot{0} \\
\stackrel{\Xi}{0}\end{array}$ & $\begin{array}{l}0 \\
\dot{0} \\
\stackrel{\rho}{9}\end{array}$ \\
\hline total land area & $\begin{array}{l}<1 \mathrm{Ha} \\
1-3 \\
>3 \mathrm{Ha}\end{array}$ & 2 & 2 & 2 & 2 & 1 & 1 & 1 \\
\hline $\begin{array}{l}\text { ready to develop } \\
\text { land (clean and } \\
\text { clear) no need to } \\
\text { land dredging or } \\
\text { sandfill except for } \\
\text { soil surface } \\
\text { forming }\end{array}$ & $\begin{array}{l}\text { ready to develop } \\
\text { soil surface } \\
\text { forming } \\
\text { dredging/sandfill } \\
\text { /illegal } \\
\text { residential }\end{array}$ & 2 & 2 & 2 & 2 & 0 & 0 & 2 \\
\hline $\begin{array}{l}\text { it is not a } \\
\text { productive land } \\
\text { such as rice fields } \\
\text { or plantations }\end{array}$ & $\begin{array}{l}\text { high productive } \\
\text { medium } \\
\text { productive } \\
\text { non productive }\end{array}$ & 0 & 0 & 0 & 0 & 1 & 0 & 0 \\
\hline it is not located in & high & & & & & & & \\
\hline
\end{tabular}




\begin{tabular}{|c|c|c|c|c|c|c|c|c|}
\hline $\begin{array}{l}\text { the disaster-prone } \\
\text { area, there will be } \\
\text { no flood or } \\
\text { landslide }\end{array}$ & $\begin{array}{l}\text { medium } \\
\text { low }\end{array}$ & 2 & 2 & 2 & 2 & 2 & 2 & 2 \\
\hline $\begin{array}{l}\text { near to the } \\
\text { residential or } \\
\text { activity center }\end{array}$ & $\begin{array}{l}>1 \mathrm{~km} \\
500 \mathrm{~m}-1 \mathrm{~km} \\
0-500 \mathrm{~m}\end{array}$ & & & & & & & \\
\hline $\begin{array}{l}\text { easy to reach with } \\
\text { easy accessibility }\end{array}$ & $\begin{array}{l}\text { cannot be } \\
\text { passed by } \\
\text { vehicles } \\
\text { can be passed } \\
\text { by } 2-4 \text { wheeled } \\
\text { vehicles } \\
\text { public } \\
\text { transportations }\end{array}$ & 2 & 1 & 2 & 1 & 2 & 1 & 1 \\
\hline $\begin{array}{l}\text { site requirement } \\
\text { based on the total } \\
\text { population }\end{array}$ & $\begin{array}{l}\text { high }>20.000 \\
\text { medium } 15.000- \\
20.000 \\
\text { low }<15.000\end{array}$ & 2 & 1 & 0 & 2 & 2 & 0 & 2 \\
\hline city service & $\begin{array}{l}\text { it has }>1 \text { public } \\
\text { service } \\
\text { it has } 1 \text { public } \\
\text { service } \\
\text { it has no public } \\
\text { service }\end{array}$ & 1 & 1 & 1 & 1 & 1 & 0 & 0 \\
\hline
\end{tabular}

\begin{tabular}{|l|l|c|c|}
\hline \multicolumn{3}{|c}{ Rank } \\
\hline \multirow{4}{*}{$\begin{array}{l}\text { Location } \\
\text { Total } \\
\text { Scoring }\end{array}$} & Location 1 & N & Mean Rank \\
\cline { 2 - 4 } & Location 3 & 8 & 73.94 \\
\cline { 2 - 4 } & Location 6 & 8 & 69.44 \\
\cline { 2 - 4 } & Location 8 & 8 & 61.63 \\
\cline { 2 - 4 } & Location 13 & 8 & 68.19 \\
\cline { 2 - 4 } & Location 14 & 8 & 62.44 \\
\cline { 2 - 4 } & Location 16 & 8 & 40.25 \\
\cline { 2 - 4 } & Total & 56 & \\
\hline
\end{tabular}

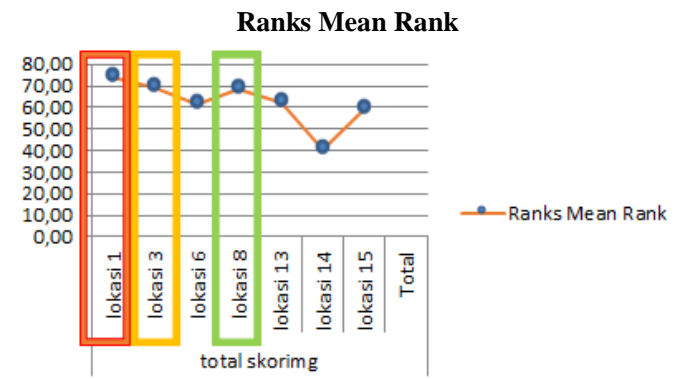

Fig. 11. The analysis result of determining factor with SPSS

From the result, the highest rank is location 1 , and then location 3, and location 8 .

Super decisions analysis used to analyze the location of Mangupura city park with the same data sequence as AHP analysis. This result is shown in table 5.12. Using the super decisions application, the most often appear location as the alternative site of Mangupura city park is 1) Location 1;2) Location 13; 3) Location 6 for the most potential site.

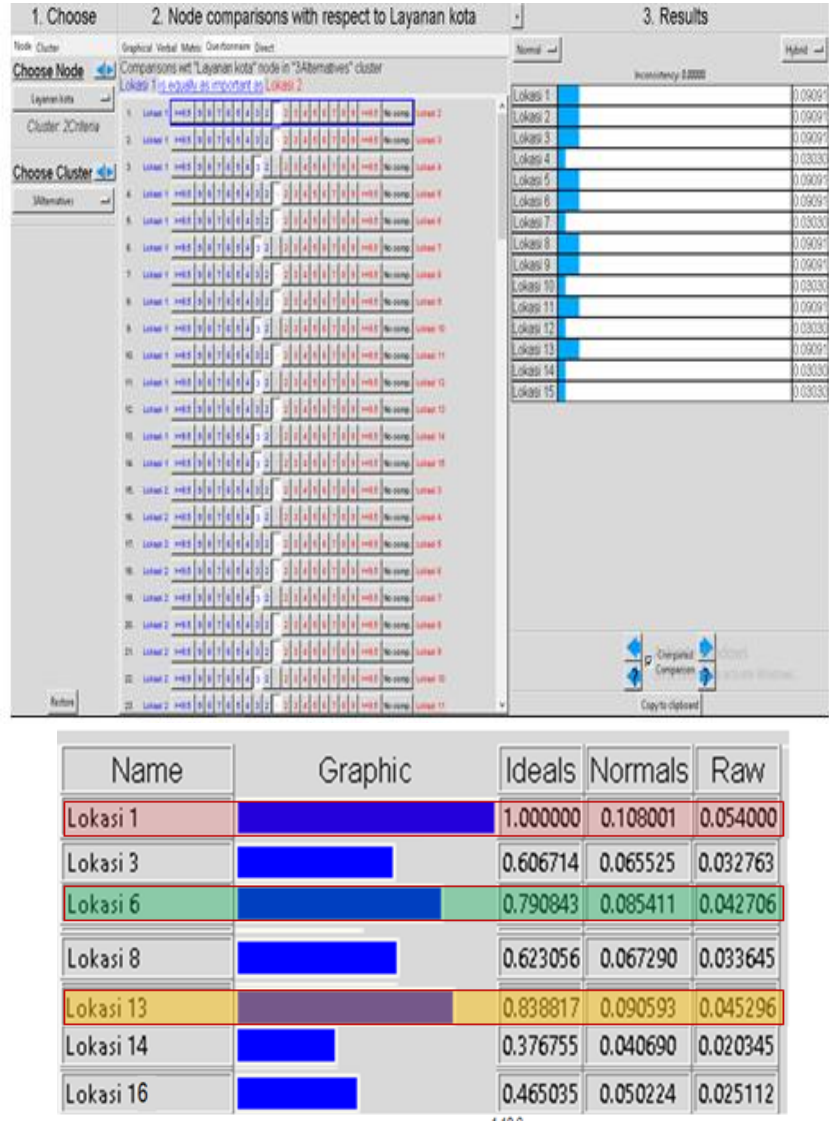

Fig. 12. Location analysis using Superdecisions method

\section{ANALYSIS RESULT AND CONCLUSION}

According to the analysis that conducted, it concluded that the alternative site analysis of Mangupura city park is as follows: 1) Based on the centrality index analysis and the area service range (isoline): the alternative sites of Mangupura city park are Location 1, Location 3, and Location 6, Location 8, Location 13, Location 14, and Location 16 ; 2) Based on the analysis result by scoring/weighting methods, it obtained 3 (three) alternative sites for Mangupura city park development, they are Location 1, Location 3, and Location 6; 3) Based on the factor analysis by SPSS, it obtained 3 (three) sequence locations: location 1, location 3, and location 8; 4) Based on the calculation result using Super Decision software (decision maker), it obtained three alternative sites: Location 1, location 6, and location 13.

From several analysis processes and weighting conducted to find the best alternative, it came up that location 1 is recommended for an open space site as Mangupura City Park. Supported by the data, it concluded that location 1 is the best.

TABLE X

THE ANALYSIS RESULTS BY APPLYING SEVERAL METHODS.

\begin{tabular}{llll}
\hline \hline No & Site Analysis Method & Result & Location \\
\hline 1 & $\begin{array}{l}\text { centrality analysis } \\
\text { index and isoline }\end{array}$ & $\begin{array}{l}\text { loc1,loc3 and loc6, } \\
\text { loc13,1 loc14 and }\end{array}$ & $\begin{array}{l}\text { Ward: Sempidi, } \\
\text { Abianbase, Kapal, }\end{array}$ \\
\hline \hline
\end{tabular}


Journal of A Sustainable Global South, p-ISSN: 2579-6062

\begin{tabular}{llll}
\hline & & loc16 & $\begin{array}{l}\text { Mengwi, and } \\
\text { Mengwitani }\end{array}$ \\
$2 \quad \begin{array}{l}\text { scoring method/AHP } \\
\text { weighting }\end{array}$ & $\operatorname{loc} 1, \operatorname{loc} 3$ and loc6 & $\begin{array}{l}\text { Sempidi ward and } \\
\text { Abianbase ward }\end{array}$ \\
& SPSS factor analysis & $\operatorname{loc} 1, \operatorname{loc} 3$ and loc8 & $\begin{array}{l}\text { Sempidi ward, } \\
\text { Mengwitani village and } \\
\text { Sempidi ward }\end{array}$ \\
& Super decision & loc1, loc6 and loc13 & $\begin{array}{l}\text { Sempidi ward and } \\
\text { Lukluk ward }\end{array}$ \\
\hline \hline
\end{tabular}

\section{REFERENCES}

[1] Wu, J. 2008. Toward a Landscape Ecology of Cities:Beyond Buildings, Trees, and Urban Forests. In Ecology, Planning, and Management of Urban Forests International Perspectives, ed. Margaret M. Carreiro, Yong-Chang Song and Jianguo Wu. New York: Springer Science+Business Media, LLC, 10-28.

[2] Rahmy, W. A., Faisal, B., \& Soeriaatmadja, A. R. 2012. Kebutuhan Ruang Terbuka Hijau Kota pada Kawasan Padat, Studi Kasus di Wilayah Tegallega, Bandung. Journal Lingkungan Binaan Indonesia, 1(1), 27-38.

[3] Inessia, dkk. 2015. Penentuan dan Pemilihan Lokasi Bandara dengan Menggunakan SIG dan Metode Analytical Hierarchy Process (Rencana Bandara di Kabupaten Kendal). Journal Geodesi Undip. Vol. 4, No. 2, 2015.

[4] Purnomohadi, S. 1995. Peran Ruang Terbuka Hijau Dalam Pengendalian Kualitas Udara di DKI Jakarta. Disertasi, Program Pascasarjana Institut Pertanian Bogor.

[5] Perloff, Harvey S. 1969. The Quality of Urban Enviroment - Essay in New Resources in Urban Age.

[6] Dirjentaru. 2008. Peraturan Menteri Pekerjaan Umum Nomor: 05/PRT/M/2008 tentang Pedoman Penyediaan dan Pemanfaatan Ruang Terbuka Hijau di Kawasan Perkotaan. Pekerjaan Umum Department.

[7] Imansari N., Khadiyanta P. 2015. Penyediaan Hutan Kota dan Taman Kota sebagai Ruang Terbuka Hijau (RTH) Publik Menurut Preferensi Masyarakat di Kawasan Pusat Kota Tangerang. Journal Ruang. Volume 1, No. 3, 2015. 101-110. Diponegoro University. Semarang. 